\title{
Association of Pediatric Obesity with Adult Cardiovascular Disease: A Narrative Review of Published Evidence
}

ISSN: 2578-0263

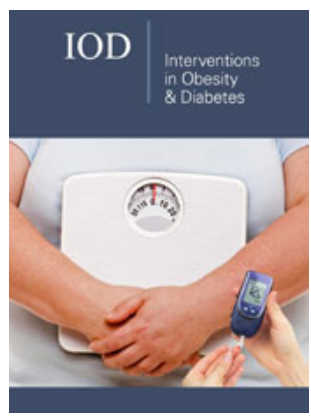

*Corresponding author: Samuel $\mathrm{N}$ Uwaezuoke, Department of Pediatrics, University of Nigeria Teaching Hospital, Ituku-Ozalla Enugu, Nigeria

Submission: 梅 September 30, 2019

Published: 䁈October 16, 2019

Volume 3 - Issue 3

How to cite this article: Uwaezuoke SN, Ayuk AC, Chikani UN, Eze JN, Adiele KD and Aronu AE. Association of pediatric obesity with adult cardiovascular disease: A narrative review of published evidence. Interventions Obes Diabetes 3(3). IOD.000561.2019.

DOI: 10.31031/IOD.2019.03.000561

Copyright@ Samuel N Uwaezuoke. This article is distributed under the terms of the Creative Commons Attribution 4.0 International License, which permits unrestricted use and redistribution provided that the original author and source are credited.

\section{Uwaezuoke SN*, Ayuk AC, Chikani UN, Eze JN, Adiele KD and Aronu AE}

Department of Pediatrics, University of Nigeria Teaching Hospital, Ituku-Ozalla Enugu, Nigeria

\begin{abstract}
There is a global increase in the prevalence of childhood and adolescent obesity. Pediatric obesity is a strong predictor of adult obesity with its attendant health consequences, and there is now substantial evidence linking it with cardiovascular diseases (CVD) in adulthood. This review aims to discuss the pathophysiologic mechanisms involved in the development of future CVD in pediatric obesity and the findings of some published longitudinal studies which reported the relationship between the two morbidities. The pathophysiologic pathways have been established, as both abnormal cardiac remodeling and abnormal vascular remodeling are the primary outcome events arising from the 'adiposopathy' of obesity. Increased left ventricular mass ( $\uparrow$ LVM) and increased left atrial ( $\uparrow$ LA) size are independent risk factors for cardiovascular morbidity and mortality in adults. Premature atherosclerotic processes may result in adult cardiovascular diseases such as coronary heart disease (CHD), cerebrovascular accident (CVA), thrombo-embolism and hypertensive heart disease. Because of the complex interplay of cardiometabolic risk confounders during the life course, there is no consensus yet on the modulating factors for disease risk from childhood to adulthood and on the best methods of measurements in children for predicting adult CVD.
\end{abstract}

Keywords: Adiposopathy; Cardio metabolic syndrome; Abnormal cardiac remodeling; Atherosclerosis; Cardiovascular diseases

\section{Introduction}

The prevalence of pediatric obesity is increasing globally because of lifestyles, which fundamentally create an imbalance that favors caloric intake over expenditure [1]. These lifestyles include sedentary habits such as addiction to computer games, internet, and television, as well as a regular intake of energy-dense fast foods [2]. Several reports reveal the health burden of childhood and adolescent obesity in both developing and developed countries [3-9]. Whereas obesity is prevalent in the lower socio-economic class in developed countries, it is more common in the upper socio-economic class in developing countries. In the latter, sedentary habits and indulgence in fast foods (nutritional transition) are regarded as signs of affluence [10]. Obesity in children and adolescents is associated with several comorbidities and complications, like hypertension [11], obstructive sleep apnea syndrome [12], orthopedic disorders [13], insulin resistance and type 2 diabetes mellitus (T2DM) $[14,15]$, dyslipidemia [16], and malignancies [17]. In the pediatric cardio-metabolic syndrome, genetic and environmental factors synergistically act as triggers; but obesity remains the primary etiologic factor which leads to hyperinsulinemia, and subsequently to hypertension and dyslipidemia [18]. Some authors have, however, proposed five diagnostic components for the syndrome, namely abdominal obesity (increased waist circumference), hyperglycemia (glucose intolerance), hypertriglyceridemia, low high-density lipoprotein-cholesterol (LDL-C) and hypertension [19]. More importantly, some of these diagnostic components are also putative risk factors for T2DM and adult cardiovascular diseases (CVD) such as coronary heart disease (CHD), cerebrovascular accident (CVA), heart failure, hypertensive heart disease, cardiac dysrhythmias, and thrombo-embolic disease.

There is now substantial evidence linking childhood and adolescent obesity with CVD in adults due to the high risks of hypertension and dyslipidemia [20-23]. Moreover, pediatric obesity is a strong predictor of adult obesity with its attendant health consequences [24]. Despite several cross-sectional studies on co-morbid CVD predictors [25-29] and longitudinal 
studies on future CVD [30-35] in obese children and adolescents, there are still gaps in clearly understanding its evolution in these age groups [36]. For instance, the best methods of measurement in children for predicting CVD later in life and the modulating factors for disease risk during the life course remain unresolved [36]. In this review, we aim to discuss the pathophysiologic mechanisms underlying the development of future CVD in pediatric obesity and the findings of some published longitudinal studies which reported the relationship between the two morbidities.

\section{Adiposopathy of Obesity and CVD}

The pathways involved in the development of obesity-driven CVD are well documented in a recent review [36]. Obesity is associated with 'adiposopathy,' which triggers major metabolic diseases (dyslipidemia, hypertension, and T2DM), resulting in two significant sequelae: abnormal vascular remodeling and abnormal cardiac remodeling (Figure 1). 'Adiposopathy' refers to the anatomic and pathophysiologic consequences of pathogenic adipose tissue (from the patient's perspective; the so-called 'sick fat') $[37,38]$. It is a disorder characterized by pathogenic adipose tissue that is sustained by positive caloric balance and sedentary lifestyle in individuals with a genetic and environmental predisposition [37]. Anatomic manifestations of obesity such as adipose hypertrophy and visceral adiposity physiologically result in endocrine and immune sequelae which eventuate in metabolic disease [39]. Thus, genetics and metabolic milieu determine when the positive caloric balance will result in adipose hypertrophy and visceral adiposity; which constitute the pathogenic precursors for the major metabolic diseases. Furthermore, the pathogenic potential of adipose tissue is also determined by its signaling exchanges with contiguous adipocytes and interactions with other body organs [37]. Finally, the functional integrity of these non-adipose organs determines the extent of the contributory role of adipose tissue to metabolic disease. Besides its frequent association with metabolic diseases like T2DM, hypertension, dyslipidemia, and cardio-metabolic syndrome, adiposopathy may also be a direct contributor to CVD, especially atherosclerosis (abnormal vascular remodeling) [40]. In summary, the pathogenic mechanisms involved in the development of these metabolic diseases include defective adipogenesis, visceral adiposity, increased net release of free fatty acids (FFA), endocrine and inflammatory responses of 'deranged' adipose tissue, as well as the altered signaling exchanges among adipocytes and the altered interactions with non-adipose tissue [37].

\section{Abnormal Vascular Remodeling: The Pathogenic Pathways}

Apart from its energy-conserving property, adipose tissue also produces several pro-inflammatory, vasoactive, and metabolic active hormones and cytokines, which are collectively referred to as adipocytokines (adipokines) [41]. These substances play a role in insulin resistance and are believed to be contributory to the evolution of atherosclerosis, T2DM, and hypertension: which could subsequently result in CVD [42]. Despite the focus on leptin, resistin, adiponectin, and interleukin-6 (IL-6), some studies linking these adipocytokines to CVD have given conflicting results [43-45]. In fact, a more recent study observed that neither adiponectin nor leptin was independently associated with CVD; thus, disputing their role in CVD [46]. Interestingly, the authors instead found that C-reactive protein (CRP) - used as IL-6 surrogate - was significantly linked with an increased risk of CVD, and also substantially reduced the CVD risk related to body mass index (BMI); they, therefore, suggested that IL-6-linked pathways may play a role in mediating obesity-related CVD [46].

Nevertheless, it is now well established that preclinical or asymptomatic atherosclerosis (abnormal vascular remodeling) commences naturally in early childhood and may be influenced over the life course by obesity [47]. Obesity-related cardiovascular risk factors may also alter the initial steps in atherosclerosis (i.e. endothelial function, arterial stiffness, adhesion molecule expression, foam cell formation, and smooth muscle proliferation) and the subsequent changes (i.e. atherosclerotic plaque rupture and thrombosis) [36]. Endothelial dysfunction is a crucial initial step in the development of CVD. It may be modulated by the duration and severity of obesity, as well as the interaction of obesity with other cardiovascular/metabolic risk factors [36]. Abnormal vascular remodeling occurs from the following complex pathophysiologic mechanisms. First, insulin resistance (the link between obesity and T2DM) may contribute to these cardiovascular sequelae via diabetes-induced endothelial dysfunction. Visceral adiposity and ectopic adipose tissue are associated explicitly with insulin resistance [48]. Other obesity-related factors that are correlated with insulin resistance also include elevated serum resist in levels [49-51], as well as the so-called 'silent inflammation' triggered by excess adipocytes [52]. In the latter, adipose tissue produces arachidonic acid which is metabolized into pro-inflammatory eicosanoids leading to the formation of new inflammatory mediators like tumor necrosis factor- $\alpha$ (TNF- $\alpha$ ) and IL-6 [52]. A chemotactic eicosanoid, called LTB4, has been suggested as the 'molecular link' between obesity and T2DM, as it binds to receptors of contiguous macrophages and activates them, resulting in 'silent inflammation' and subsequent insulin resistance [52]. Also, excessive TNF- $\alpha$ has earlier been noted to contribute to insulin resistance, given its ability to inhibit lipogenesis, promote lipolysis ( $\uparrow F F A$ ), and disrupt insulin signaling [53]. Second, dyslipidemia from the 'adiposopathy' of obesity ( $\uparrow$ triglycerides and $\uparrow L D L-C$ ) is also known to initiate the early development of atherosclerosis by the formation and deposition of atherosclerotic plaque: one of the late stages in endothelial dysfunction (Figure 2). Third, physiologic levels of adiponectin has several anti-atherosclerotic activities such as the inhibition of monocyte adhesion to aortic endothelial cells and downregulation of the expression of adhesion molecules on these cells [54], the suppression of aortic smooth muscle cell proliferation and migration [55], the inhibition of macrophage foam-cell transformation [56], as well as the increased production of tissue metalloproteinase inhibitor-1 (TIMP-1): a modulator of atherosclerotic plaque rupture [57]. In 'adiposopathy', adiponectin levels are reduced and thus promote the development of atherosclerosis. Low adiponectin levels have been reported to be associated with endothelial dysfunction in childhood and adulthood [58], as well as with higher evolution of coronary artery calcification (arterial stiffness) and thicker carotid intima-media 
thickness (IMT) in adolescents [59,60]. Although there is higher IMT in obese children and adolescents in comparison with their non-obese counterparts $[27,61,62]$, some investigators did not report any difference despite changes in endothelial function and arterial stiffness $[63,64]$. Nevertheless, aortic IMT and carotid IMT are regarded as surrogate markers of atherosclerosis as well as indirect evidence of disease progression [65].

\section{Abnormal Cardiac Remodeling: The Pathogenic Mechanisms}

The cardiac chambers are affected by obesity-related hemodynamic changes, which can occur both in children and adults $[66,67]$. There is now enough evidence to suggest that the influence of childhood obesity on cardiac structure persists into adult life and may worsen the cardiac effects of obesity in adulthood [36]. Childhood and adolescent adiposity exert significant influences on cardiac structure and function, particularly on the left ventricle [68]. Notably, left ventricular muscle thickness, quantitatively measured as left ventricular mass (LVM), is a stand-alone risk factor for cardiovascular morbidity and mortality [69]. Several studies have shown that LVM is increased in obese children and adolescents when compared with their normal-weight counterparts $[22,70,71]$, and also has a linear relationship with childhood BMI [72]. However, central adiposity (excess visceral adiposity) appears to have a better correlation with LVM in children [73], given its link with CVD [74]. Similarly, left atrial (LA) size is directly related to BMI in children [75], with a larger LA size observed more frequently in obese than in non-obese children [76]. Also, LA size has been noted to be an independent risk factor for atrial fibrillation, cardiac failure and CVA in adulthood [77].

The mechanisms behind the abnormal cardiac remodeling are based on the hemodynamic effects of adiposopathy. Systemic and pulmonary hypertension (related to adiposopathy) directly affects cardiac remodeling leading to abnormalities like increased LA size ( $\uparrow$ LA size) and LVM ( $\uparrow$ LVM) (Figure 1). The pathogenic trajectory comprises the increased sympathetic activity from adiposopathy, which leads to an increase in circulating blood volume, increased stroke volume, and increased heart rate. This hemodynamics may directly influence the left atrial and ventricular functions leading to chamber strains: with the consequent $\uparrow$ LA size and $\uparrow L V M$. However, assessment of atrial phasic function with atrial strain has not been reported in childhood obesity [36], as some authors thus advance the hypothesis that obesity-related $\uparrow$ LA size may be linked to abnormalities in ventricular mechanics (especially diastolic dysfunction) seen in childhood obesity [78], and adult obesity [79]. In a nutshell, obesity affects cardiac muscle through several mechanisms [80]. It can singularly cause chronic volume overload and associated higher cardiac output [81]. Both hemodynamic and metabolic factors linked to obesity can cause structure-function changes of the myocardium leading to $\uparrow$ LVM. Also, obesity-related hypertension increases the work of the heart and stimulates cardiac growth while obesity-associated oxidative stress, inflammation, and activation of the renin-angiotensin system (RAS) can trigger cardiac remodeling with increased cardiac myocyte and connectivetissue matrix accumulation [82-84].

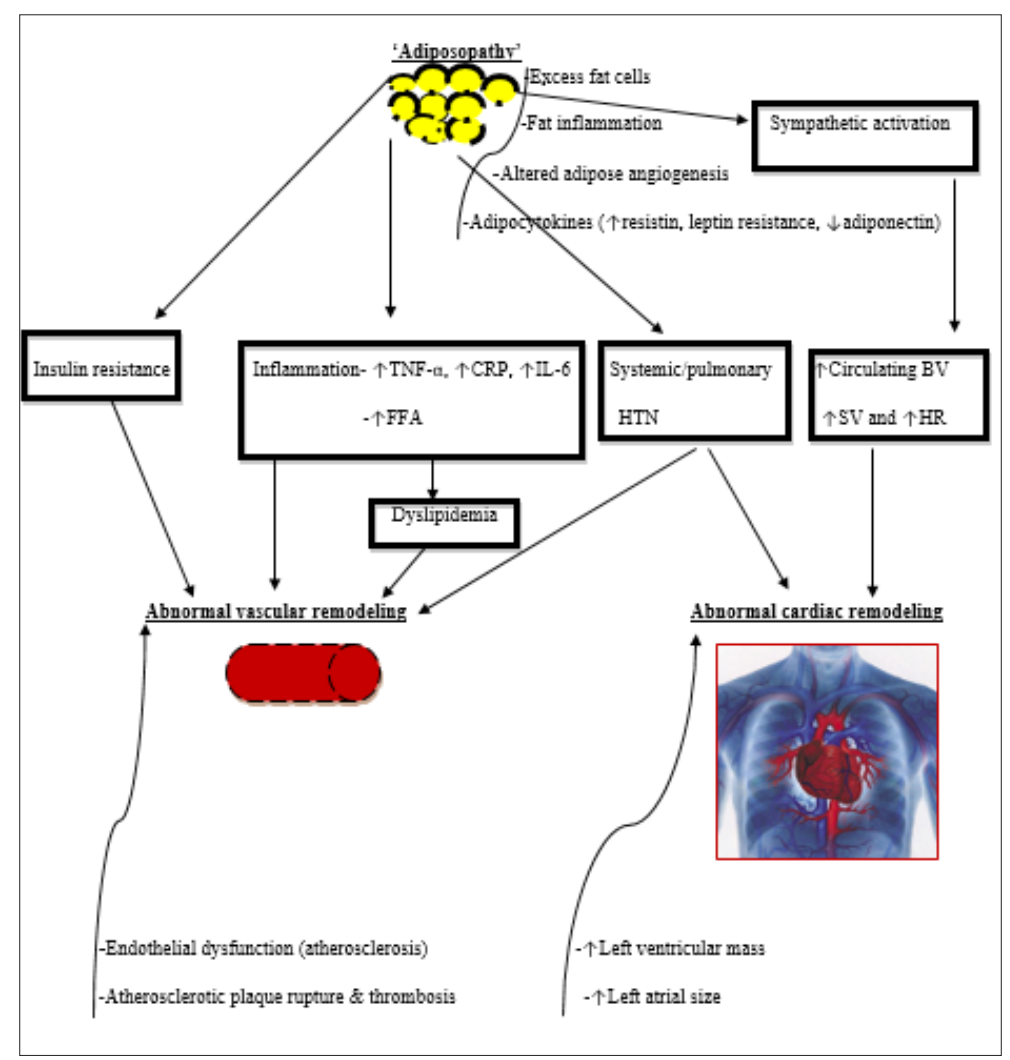

Figure 1: The pathophysiologic mechanisms of cardiovascular disease in obesity [34]. TNF-a, tumor necrosis factor-alpha CRP, C-reactive protein IL-6, interleukin-6 FFA, free fatty acids HTN, hypertension BV, blood volume $\mathrm{SV}$, stroke volume HR, heart rate. 


\section{Pediatric Obesity Versus Adult CVD: Some Longitudinal Studies}

In a population-based, multi-center, prospective cohort study in Finland, Raitakari et al. [30] investigated the cardiovascular risk factors of 2229 Caucasian male and female subjects: first in early childhood and adolescence (age 3 to 18 years) and 21 years later in adulthood (age 24 to 39 years). The authors aimed to study the association of cardiovascular risk-factor profiles assessed in childhood and adolescence with carotid artery intima-media thickness (cIMT) measured in adulthood as a surrogate marker of preclinical atherosclerosis. Specifically, there was a statistically significant association of cIMT in adulthood with LDL-C levels, systolic blood pressure, and BMI in childhood, as well as with adult systolic blood pressure. More importantly, the cardiovascular riskfactor profiles (high levels of LDL-C, systolic blood pressure, BMI and cigarette smoking) measured at adolescence (age 12 to 18 years) were directly related to cIMT measured in adulthood (age 33 to 39 years) in both sexes (Table 1). These findings confirm the previous observations about the utility of ultrasonographic measurement of cIMT as a marker of preclinical atherosclerosis because of its known correlation with cardiovascular risk factors [85], its relationship with the severity and degree of CHD [86], and its predictive ability for possible cardiovascular events $[87,88]$.

Elsewhere in the United States, the community-based Bogalusa Heart Study was conducted among biracial (Caucasian and Negroid) subjects by Li et al. [32]. Their study objective was to examine the effect of putative $\mathrm{CV}$ risk factors measured from childhood to adulthood on LVM measured in young adults. Multiple observations were made during childhood (age 4 to 17 years) and young adulthood (age 18 to 38 years), which enabled an assessment of the cumulative burden of $\mathrm{CV}$ risk-factor variables commencing in childhood. A total of 1420 subjects were studied. A 2D M-mode echocardiography examination was performed on 467 subjects in adulthood. Other assessments conducted from childhood to adulthood were BMI, systolic and diastolic blood pressure, highdensity lipoprotein-cholesterol (HDL-C) and triglycerides (TG), and cholesterol levels. Using multiple regression analyses, the authors found that adiposity (measured as BMI) in childhood, adiposity and systolic blood pressure in adulthood, and the cumulative burden of adiposity and systolic blood pressure from childhood to adulthood were significant predictors of LVM index in young adults [32] (Table 1). Their findings buttress the fact that the cumulative burden of risk factor profiles in childhood was more likely to result in $\uparrow L V M$ in adulthood than increased adiposity and hypertension which were previously identified as the two major factors leading to excessive cardiac growth in children [89], and adults [90]. In another longitudinal study, Bjørge et al. [33] in Norway evaluated the long-term effects of adolescent obesity on cause-specific mortality. The authors studied 227,000 adolescents (aged 14 to 19 years) and compared the cause-specific mortality among subjects whose baseline BMI was below the $25^{\text {th }}$ percentile, between the $75^{\text {th }}$ and $84^{\text {th }}$ percentiles, and above the $85^{\text {th }}$ percentile in a US reference population with that of subjects whose BMI was between the $25^{\text {th }}$ and $75^{\text {th }}$ percentiles. In a 22-year old follow-up, relative risks of death from ischemic heart disease and other mortalities were observed for both males and females in the highest BMI percentile category (Table 1).

Table 1: Summary of findings from some longitudinal studies on childhood and adolescent obesity versus adult cardiovascular disease. $\dagger$ Age range at first investigation, $\dagger \dagger$ Age range at second investigation, $\ddagger$ Assessed by ultrasound, $\S$ Assessed by 2D M-mode echocardiography LDL-C, low-density lipoprotein cholesterol HDL-C, high-density lipoprotein cholesterol TG, triglycerides BP, blood pressure BMI, body mass index cIMT, common carotid artery intima-media thickness LVM, left ventricular mass, CVD, cardiovascular disease CHD, coronary heart disease CVA, cerebrovascular accident.

\begin{tabular}{|c|c|c|c|c|c|}
\hline $\begin{array}{l}\text { Authors (year)/ } \\
\text { Country }\end{array}$ & Type of Study & $\begin{array}{l}\text { Study popula- } \\
\text { tion }\end{array}$ & $\begin{array}{l}\text { Outcome Measures } \\
\text { in Childhood and } \\
\text { Adolescence }\end{array}$ & $\begin{array}{l}\text { Outcome Measures } \\
\text { in Adulthood }\end{array}$ & Major Study Findings \\
\hline \multirow{6}{*}{$\begin{array}{c}\text { Raitakari et al. [30] } \\
\text { (2003)/Finland }\end{array}$} & \multirow{6}{*}{$\begin{array}{l}\text { A popula- } \\
\text { tion-based, } \\
\text { multi-center, } \\
\text { prospective } \\
\text { cohort study }\end{array}$} & $\begin{array}{l}2229 \text { Caucasian } \\
\text { subjects }\end{array}$ & -LDL-C & -LDL-C & \multirow{6}{*}{$\begin{array}{l}\text {-Cardiovascular risk-factor profiles } \\
\text { measured at } 12 \text { to } 18 \text { years were better } \\
\text { predictors of adult cIMT }\end{array}$} \\
\hline & & $\begin{array}{l}\text {-aged } 3 \text { to } 18 \\
\text { years }^{\dagger}\end{array}$ & -HDL-C \& TG & -HDL-C \& TG & \\
\hline & & $\begin{array}{l}\text {-aged } 24 \text { to } 39 \\
\text { years }^{\dagger+}\end{array}$ & -LDL-C/HDL-C ratio & -LDL-C/HDL-C ratio & \\
\hline & & & $\begin{array}{c}\text {-Systolic \& Diastolic } \\
\text { BP }\end{array}$ & $\begin{array}{c}\text {-Systolic \& Diastolic } \\
\text { BP }\end{array}$ & \\
\hline & & & -BMI \& Smoking & -BMI \& Smoking & \\
\hline & & & & - cIMT $^{\ddagger}$ & \\
\hline
\end{tabular}




\begin{tabular}{|c|c|c|c|c|c|}
\hline \multirow{3}{*}{$\begin{array}{l}\text { Juonala et al. [31] } \\
\text { (2010)/Finland }\end{array}$} & \multirow{3}{*}{$\begin{array}{l}\text {-Multi-center, } \\
\text { prospective } \\
\text { cohort study* }\end{array}$} & 4380 subjects & \multirow{3}{*}{$\begin{array}{l}\text {-Cardiovascular risk } \\
\text { factor data (total } \\
\text { Cholesterol, TG, BP } \\
\text { \& BMI) }\end{array}$} & \multirow{3}{*}{-cIMT } & \multirow{3}{*}{$\begin{array}{c}\text {-Cardiovascular risk factor measure- } \\
\text { ments obtained at or after } 9 \text { years } \\
\text { of age in childhood and adolescence } \\
\text { were significantly predictive of cIMT in } \\
\text { adulthood }\end{array}$} \\
\hline & & -3 to 18 years $^{\dagger}$ & & & \\
\hline & & $\begin{array}{l}-20 \text { to } 45 \\
\text { years }^{\dagger+}\end{array}$ & & & \\
\hline \multirow{5}{*}{$\begin{array}{l}\text { Li et al. [32]- The } \\
\text { Bogalusa Heart Study } \\
\text { (2004)/United States }\end{array}$} & \multirow{5}{*}{$\begin{array}{l}\text { Communi- } \\
\text { ty-based, } \\
\text { cross-sectional } \\
\text { surveys and lon- } \\
\text { gitudinal study }\end{array}$} & $\begin{array}{l}1420 \text { Caucasian } \\
\text { and Negroid } \\
\text { subjects }\end{array}$ & -BMI & -BMI & \multirow{5}{*}{$\begin{array}{l}\text {-Adiposity (measured as BMI) in } \\
\text { childhood, adiposity and systolic BP in } \\
\text { adulthood, and the cumulative burden } \\
\text { of adiposity and systolic BP from child- } \\
\text { hood to adulthood were significant } \\
\text { predictors of LVM index in young adults }\end{array}$} \\
\hline & & $\begin{array}{l}\text {-aged } 4 \text { to } 17 \\
\text { years }^{\dagger}\end{array}$ & $\begin{array}{c}\text {-Systolic \& Diastolic } \\
\text { BP }\end{array}$ & $\begin{array}{c}\text {-Systolic \& Diastolic } \\
\text { BP }\end{array}$ & \\
\hline & & $\begin{array}{l}\text {-aged } 18 \text { to } 38 \\
\text { years }^{\dagger \dagger}\end{array}$ & -HDL-C \& TG & -HDL-C \& TG & \\
\hline & & & -Cholesterol & -Cholesterol & \\
\hline & & & & $-\mathrm{LVM}^{\S}$ & \\
\hline \multirow{3}{*}{$\begin{array}{l}\text { Bjørge et al. [33] } \\
\text { (2008)/Norway }\end{array}$} & \multirow{3}{*}{$\begin{array}{l}\text { Popula- } \\
\text { tion-based longi- } \\
\text { tudinal study }\end{array}$} & $\begin{array}{l}227000 \text { sub- } \\
\text { jects }\end{array}$ & \multirow{3}{*}{$\begin{array}{l}\text {-BMI (values com- } \\
\text { pared with different } \\
\text { BMI percentile cate- } \\
\text { gories) }\end{array}$} & \multirow{3}{*}{$\begin{array}{l}\text {-The relative risk of } \\
\text { death from endo- } \\
\text { crine, nutritional \& } \\
\text { metabolic diseases, } \\
\quad \text { and CVD }\end{array}$} & \multirow{3}{*}{$\begin{array}{l}\text {-Relative risks of death from ischemic } \\
\text { heart disease and other mortalities } \\
\text { noted for both sexes in the highest BMI } \\
\text { category }\end{array}$} \\
\hline & & $\begin{array}{l}\text {-aged } 14-19 \\
\text { years }^{\dagger}\end{array}$ & & & \\
\hline & & $\begin{array}{l}\text {-aged } 36-41 \\
\text { years }^{\dagger \dagger}\end{array}$ & & & \\
\hline \multirow{3}{*}{$\begin{array}{l}\text { Twig et al. [34] } \\
\text { (2016)/Israel }\end{array}$} & \multirow{3}{*}{$\begin{array}{l}\text { Popula- } \\
\text { tion-based longi- } \\
\text { tudinal study }\end{array}$} & $\begin{array}{l}2,298,130 \text { male } \\
\text { Jewish subjects }\end{array}$ & \multirow{3}{*}{$\begin{array}{l}\text {-BMI (according to } \\
\text { age- and sex-specific } \\
\text { percentiles from } \\
\text { the U.S. Centers for } \\
\text { Disease Control and } \\
\text { Prevention) }\end{array}$} & \multirow{3}{*}{$\begin{array}{l}\text {-The number of } \\
\text { deaths attributed to } \\
\text { CHD, CVA, sudden } \\
\text { death from an } \\
\text { unknown cause, or } \\
\text { a combination of } \\
\text { all three categories } \\
\text { (total cardiovascular } \\
\text { causes) }\end{array}$} & \multirow{3}{*}{$\begin{array}{l}\text {-A BMI in the 50th to } 74 \text { th percentiles, } \\
\text { within the accepted normal range, } \\
\text { during adolescence was associated with } \\
\text { increased cardiovascular and all-cause } \\
\text { mortality during } 40 \text { years of follow-up }\end{array}$} \\
\hline & & -16 to 19 years $^{\dagger}$ & & & \\
\hline & & $\begin{array}{l}-56 \text { to } 59 \\
\text { years }^{\dagger \dagger}\end{array}$ & & & \\
\hline
\end{tabular}

The Finnish prospective cohort study by Juonala et al. [31] employed data for 4380 subjects of 4 prospective cohortsCardiovascular Risk in Young Finns Study (Finland), Childhood Determinants of Adult Health Study (Australia), Bogalusa Heart Study (United States), and Muscatine Study (United States)-which have gathered cardiovascular risk factor profiles from childhood (age 3 to 18 years) and subsequently performed cIMT estimations in adulthood (age 20 to 45 years) [31]. Interestingly, the authors found that the number of childhood risk factors (namely high total cholesterol, TG, blood pressure, and BMI) was significantly predictive of increased cIMT based on risk factors estimated at the ages of 9 years, 12 years, 15 years, and 18 years (Table 1). On the other hand, the associations with risk factors estimated at ages three years and six years were found to be nonsignificant: making the authors conclude that risk factor profiles obtained at or after nine years of age were predictive of preclinical atherosclerosis in adulthood [31]. These observations are not surprising given that atherosclerotic processes which begin in early childhood progress over the life course and are worsened by obesity and other cardiometabolic factors (Figure 2). Finally, the study by Twig et al. [34] was based on a national database of 2.3 million Israeli male adolescents in whom the BMI was estimated for over 40 years. The investigators evaluated the relationship between the BMI in late adolescence and mortality from CHD, CVA, and sudden death in adulthood. During 42,297,007 person-years of follow-up, 2918 of 32,127 deaths $(9.1 \%)$ were from cardiovascular causes, including 1497 from CHD, 528 from CVA, and 893 from sudden death. A BMI in the $50^{\text {th }}$ to $74^{\text {th }}$ percentiles (within the accepted normal range) during adolescence was associated with increased cardiovascular and all-cause mortality during the 40 years of follow-up (Table 1). These findings are in tandem with those of other studies which suggest that a BMI within the upper-normal range in adolescence is associated with an increased risk of death from cardiovascular causes $[34,91,92]$. Two pathways by which adolescent BMI probably determine cardiovascular outcomes in adulthood have been highlighted [35]. The first is the obesity-linked cardiovascular and metabolic abnormalities (previously stated) such as abnormal plasma lipid or lipoprotein levels, hypertension, impaired glucose metabolism, and insulin resistance $[20,93]$, cardiac remodeling [94], as well as the formation of coronary and aortic atherosclerotic plaques. 


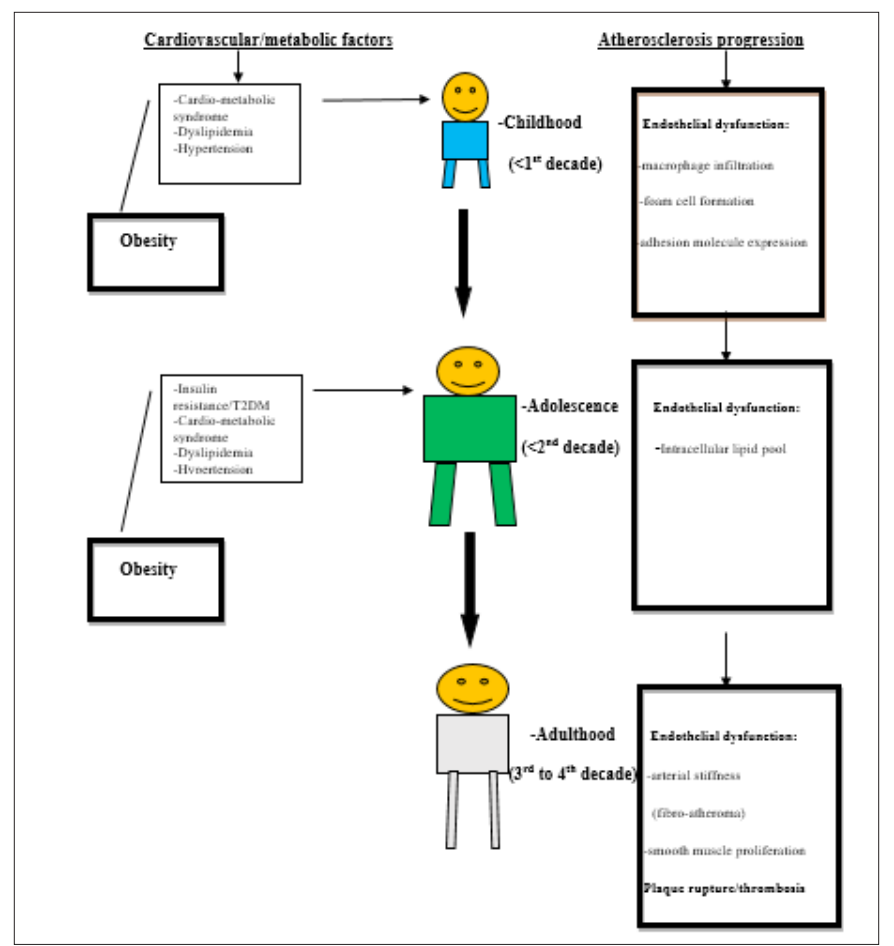

Figure 2: Effects of obesity versus stages of endothelial dysfunction in atherosclerosis over the life course N/B: Obesity causes premature development of atherosclerosis over the life course through 'adiposopathy.'

\section{Conclusion}

Obesity in childhood and adolescence is associated with an increased risk of cardiovascular diseases in adulthood. The pathophysiologic pathways have been established, as abnormal cardiac remodeling and vascular remodeling remains the main outcome events. Abnormalities of cardiac remodeling like $\uparrow$ LVM and $\uparrow$ LA are independent risk factors for cardiovascular morbidity and mortality in adults, whereas abnormal vascular remodeling like atherosclerotic processes (which if symptomatic in the late stages) may lead to adult cardiovascular diseases such as CHD, CVA, thrombo-embolism and hypertensive heart disease. Because of the complex interplay of cardio-metabolic risk confounders during the life course, there is no consensus yet on the modulating factors for disease risk from childhood to adulthood and on the best methods of measurements in children for predicting adult CVD.

\section{Acknowledgment}

The authors acknowledge the invaluable information obtained from the article by Ayer et al. [35].

\section{References}

1. Biro FM, Wien M (2010) Childhood obesity and adult morbidities. Am J Clin Nutr 91(5): 1499S-1505S.

2. Eke CB, Ubesie AC, Ibe BC (2015) Challenges of childhood obesity in a developing economy: A review. Niger J Paed 42(3):169-179.

3. Ubesie AC, Okoli CV, Uwaezuoke SN, Ikefuna AN (2016) Affluence and adolescent obesity in a city in south-east Nigeria: A cross-sectional survey. Ann Trop Med Public Health 9(4): 251-254.
4. Choukem S, Kamdeu Chedeu J, Leary SD, Mboue Djieka Y, Nebongo DN, et al. (2017) Overweight and obesity in children aged 3-13 years in urban Cameroon: A cross-sectional study of prevalence and association with socioeconomic status. BMC Obesity 4:7.

5. Ulijaszek S (2003) Obesity: preventing and managing the global epidemic; Report of a WHO consultation on obesity. J Biosoc Sci 35(4): 624-625.

6. Ogden CL, Carroll MD, Kit BK, Flegal KM (2014) Prevalence of childhood and adult obesity in the United States, 2011-2012. JAMA 311(8): 806814.

7. Jain S, Pant B, Chopra H, Tiwari R (2010) Obesity among adolescents of affluent public schools in Meerut. Indian J Public Health 54(3): 158-160.

8. Ellulu M, Abed Y, Rahmat A, Ranneh Y, Ali F (2014) Epidemiology of obesity in developing countries: Challenges and prevention. Glob Epidemiol Obes 2: 1-6.

9. I Allemand D, Wiegand S, Reinehr T, Müller J, Wabitsch M, et al. (2008) Cardiovascular risk in 26,008 overweight European children as established by a multicenter database. Obesity (Silver Spring) 16(7): 1672-1679.

10. Poskitt EM (2009) Countries in transition: Underweight to obesity nonstop? Ann Trop Paediatr 29(1): 1-11.

11. Oduwole AA, Ladipo TA, Fajolu IB, Ekure EN, Adeniyi OF (2012) Obesity and elevated blood pressure among adolescents in Lagos, Nigeria: A cross-sectional study. BMC Public Health 12:616.

12. Verhulst SL, Schrauwen N, Haentjens D, Suys B, Rooman RP, et al. (2007) Sleep-disordered breathing in overweight and obese children and adolescents: Prevalence, characteristics, and the role of fat distribution. Arch Dis Child 92(3): 205-208.

13. Taylor ED, Theim KR, Mirch MC, Ghorbani S, Tanofsky Kraff M, et al. (2006) Orthopedic complications of overweight in children and adolescents. Pediatrics 117(6): 2167-2174. 
14. Kurtoğlu S, Hatipoğlu N, Mazıcıoğlu M, Kendirici M, Keskin M, et al. (2010) Insulin resistance in obese children and adolescents: HOMA-IR cut-off Levels in the prepubertal and pubertal periods. J Clin Res Pediatr Endocrinol 2(3): 100-106.

15. Invitti C, Guzzaloni G, Gilardini L, Morabito F, Viberti G (2003) Prevalence and concomitants of glucose intolerance in European obese children and adolescents. Diabetes Care 26(1): 118-124.

16. Musso C, Graffigna M, Soutelo J, Honfi M, Ledesma L, et al. (2011) Cardiometabolic risk factors as apolipoprotein B, triglyceride/HDLcholesterol ratio and C-reactive protein, in adolescents with and without obesity: Cross-sectional study in middle-class suburban children. Pediatr Diabetes 12(3): 229-234.

17. Berger NA (2018) Young adult cancer: Influence of the obesity pandemic. Obesity 26(4): 641-650.

18. Daniels SR, Arnett DK, Eckel RH, Gidding SS, Hayman LL, et al. (2005) Overweight in children and adolescents: Pathophysiology, consequences, prevention, and treatment. Circulation 111(15): 1999-2012.

19. De Ferranti SD, Gauvreau K, Ludwig DS, Neufeld EJ, Newburger JW, et al. (2004) Prevalence of the metabolic syndrome in American adolescents: Findings from the Third National Health and Nutrition Examination Survey. Circulation 110(16): 2494-2497.

20. Skinner AC, Perrin EM, Moss LA, Skelton JA (2015) Cardio-metabolic risks and severity of obesity in children and young adults. N Engl J Med 373: 1307-1317.

21. Hanevold C, Waller J, Daniels S, Portman R, Sorof J (2004) The effects of obesity, gender, and ethnic group on left ventricular hypertrophy and geometry in hypertensive children: A collaborative study of the International Pediatric Hypertension Association. Pediatrics 113(2): 328-333.

22. Chinali M, De Simone G, Roman MJ, Lee ET, Best LG, et al. (2006) Impact of obesity on cardiac geometry and function in a population of adolescents: The Strong Heart Study. J Am Coll Cardiol 47(11): 2267-2273.

23. Cote AT, Harris KC, Panagiotopoulos C, Sandor GG, Devlin AM (2013) Childhood obesity and cardiovascular dysfunction. J Am Coll Cardiol 2013 62: 1309-1319.

24. Wang LY, Chyen D, Lee S, Lowry R (2008) The association between body mass index in adolescence and obesity in adulthood. J Adolesc Health 42(5): 512-518.

25. Meyer AA, Kundt G, Steiner M, Schuff Werner P, Kienast W (2006) Impaired flow-mediated vasodilation, carotid artery intima-media thickening, and elevated endothelial plasma markers in obese children: The impact of cardiovascular risk factors. Pediatrics 117(5):1560-1567.

26. Yilmazer MM, Tavli V, Carti OU, Mese T, Guven B, et al. (2010) Cardiovascular risk factors and noninvasive assessment of arterial structure and function in obese Turkish children. Eur J Pediatr 169(10): 1241-1248.

27. Iannuzzi A, Licenziati MR, Acampora C, Salvatore V, Auriemma L, et al. (2004) Increased carotid intima-media thickness and stiffness in obese children. Diabetes Care 27(10): 2506-2508.

28. Urbina EM, Kimball TR, Khoury PR, Daniels SR, Dolan LM (2010) Increased arterial stiffness is found in adolescents with obesity or obesity-related type 2 diabetes mellitus. J Hypertens 28(8): 1692-1698.

29. Mehta SK (2014) Left ventricular mass in children and adolescents with elevated body mass index and normal waist circumference. Am J Cardiol 113(6): 1054-1057.

30. Raitakari OT, Juonala M, Kahonen M, Taittonen L, Laitinen E, et al. (2003) Cardiovascular risk factors in childhood and carotid artery intimamedia thickness in adulthood: The Cardiovascular Risk in Young Finns Study. JAMA 290(17): 2277-2283.

31. Juonala M, Magnussen CG, Venn A, Dwyer T, Burns TL, et al. (2010) Influence of age on associations between childhood risk factors and carotid intima-media thickness in adulthood: The Cardiovascular Risk in Young Finns Study, the Childhood Determinants of Adult Health Study, the Bogalusa Heart Study, and the Muscatine Study for the International Childhood Cardiovascular Cohort (i3C) Consortium. Circulation 122(24): 2514-2520.

32. Li X, Li S, Ulusoy E, Chen W, Srinivasan SR, et al. (2004) Childhood adiposity as a predictor of cardiac mass in adulthood: The Bogalusa Heart Study. Circulation 110(22): 3488-3492.

33. Bjørge T, Engeland A, Tverdal A, Smith GD (2008) Body mass index in adolescence in relation to cause-specific mortality: A follow-up of 230,000 Norwegian adolescents. Am J Epidemiol 168(1): 30-37.

34. Twig G, Yaniv G, Levine H, Leiba A, Goldberger N, et al. (2016) Body-mass index in 2.3 million adolescents and cardiovascular death in adulthood. N Engl J Med 374: 2430-2440.

35. Ayer J, Charakida M, Deanfield JE, Celermajer DS (2015) Lifetime risk: Childhood obesity and cardiovascular risk. Eur Heart J 36(22): 13711376.

36. Bays HE, González Campoy JM, Henry RR, Bergman DA, Kitabchi AE, et al. (2008) Is adiposopathy (sick fat) an endocrine disease? Int J Clin Pract 62(10): 1474-1483.

37. Bays H, Abate N, Chandalia M (2005) Adiposopathy: Sick fat causes high blood sugar, high blood pressure, and dyslipidemia. Future Cardiol 1(1): 39-59.

38. Bays HE, Gonzalez Campoy JM, Bray GA, Kitabchi AE, Bergman DA, et al. (2008) Pathogenic potential of adipose tissue and metabolic consequences of adipocyte hypertrophy and increased visceral adiposity. Expert Rev Cardiovasc Ther 6(3): 343-368.

39. Bays H, Ballantyne C (2006) Adiposopathy: why do adiposity and obesity cause metabolic disease? Future Lipidol 1(4): 389-420.

40. Cao H (2014) Adipocytokines in obesity and metabolic disease. J Endocrinol 220(2): T47-59.

41. Mattu HS, Randeva HS (2013) Role of adipokines in cardiovascular disease. J Endocrinol 216(1): T17- 36.

42. Golia E, Limongelli G, Natale F, Fimiani F, Maddaloni V, et al. (2014) Adipose tissue and vascular inflammation in coronary artery disease. World J Cardiol 6(7): 539-554.

43. Van Gaal LF, Mertens IL, De Block CE (2006) Mechanisms linking obesity with cardiovascular disease. Nature 444: 875-880.

44. Van de Voorde J, Pauwels B, Boydens C, Decaluwé (2013) Adipocytokines in relation to cardiovascular disease. Metabolism 62(11): 1513-1521.

45. Seven E, Husemoen LLN, Sehested TSG, Ibsen H, Wachtell K, et al. (2015) Adipocytokines, C - reactive protein, and cardiovascular disease: A population-based prospective study. PLoS ONE 10(6): e0128987.

46. Hayman LL, Meininger JC, Daniels SR, McCrindle BW, Helden L, et al. (2007) Primary prevention of cardiovascular disease in nursing practice: Focus on children and youth: A scientific statement from the American Heart Association Committee on Atherosclerosis, Hypertension, and Obesity in Youth of the Council on Cardiovascular Disease in the Young, Council on Cardiovascular Nursing, Council on Epidemiology and Prevention, and Council on Nutrition, Physical Activity, and Metabolism. Circulation 116(3): 344-357.

47. Uwaezuoke SN (2015) Childhood diabetes mellitus and the double burden of malnutrition: An emerging public health challenge in developing countries. J Diabetes Metab 6(9): 597.

48. Silha JV, Krsek M, Skrha JV, Sucharda P, Nyomba BL, et al. (2003) Plasma resistin, adiponectin, and leptin levels in lean and obese subjects: Correlations with insulin resistance. Eur J Endocrinol 149(4): 331-335.

49. Steppan CM, Bailey ST, Bhat S, Brown EJ, Banerjee RR, et al. (2001) The hormone resistin links obesity to diabetes. Nature 409(6818): 307-312.

50. Fujinami A, Obayashi H, Ohta K, Ichimura T, Nishimura M, et al. (2004) Enzyme-linked immunosorbent assay for circulating human resistin: 
Resistin concentrations in normal subjects and patients with type 2 diabetes. Clin Chim Acta 339(1-2): 57-63.

51. Pingping Li, Da Young Oh, Bandyopadhyay G, Lagakos WS, Talukdar S, et al. (2015) LTB4 promotes insulin resistance in obese mice by acting on macrophages, hepatocytes, and myocytes. Nature Med 21(3): 239-247.

52. Peraldi P, Spiegelman B (1998) TNF-alpha and insulin resistance: summary and future prospects. Mol Cell Biochem 182(1-2): 169-175.

53. Ouchi N, Kihara S, Arita Y, Maeda K, Kuriyama H, et al. (1999) Novel modulator for endothelial adhesion molecules: Adipocyte-derived plasma protein adiponectin. Circulation 100(25): 2473-2476.

54. Arita Y, Kihara S, Ouchi N, Maeda K, Kuriyama H, et al. (2002) Adipocytederived plasma protein adiponectin acts as a platelet-derived growth factor-BB-binding protein and regulates growth factor-induced common post-receptor signal in vascular smooth muscle cell. Circulation 105(24): 2893-2898.

55. Ouchi N, Kihara S, Arita Y, Nishida M, Matsuyama A, et al. (2001) Adipocyte-derived plasma protein, adiponectin, suppresses lipid accumulation and class A scavenger receptor expression in human monocyte-derived macrophages. Circulation 103(8): 1057-1063.

56. Kumada M, Kihara S, Ouchi N, Kobayashi H, Okamoto Y, et al. (2004) Adiponectin specifically increased tissue inhibitor of metalloproteinase-1 through interleukin-10 expression in human macrophages. Circulation 109(17): 2046-2049.

57. Shimabukuro M, Higa N, Asahi T, Oshiro Y, Takasu N, et al. (2003) Hypoadiponectinemia is closely linked to endothelial dysfunction in man. J Clin Endocrinol Metab 88(7): 3236-3240.

58. Maahs DM, Ogden LG, Kinney GL, Wadwa P, Snell Bergeon JK, et al. (2005) Low plasma adiponectin levels predict progression of coronary artery calcification. Circulation 111(6): 747-753.

59. Pilz S, Horejsi R, Moller R, Almer G, Scharnagl H, et al. (2005) Early atherosclerosis in obese juveniles is associated with low serum levels of adiponectin. J Clin Endocrinol Metab 90(8): 4792-4796.

60. Woo KS, Chook P, Yu CW, Sung RY, Qiao M, et al. (2004) Overweight in children is associated with arterial endothelial dysfunction and intimamedia thickening. Int J Obes Relat Metab Disord 28(7): 852-857.

61. Zhu W, Huang X, He J, Li M, Neubauer H (2005) Arterial intima-media thickening and endothelial dysfunction in obese Chinese children. Eur J Pediatr 164(6): 337-344.

62. Tounian P, Aggoun Y, Dubern B, Varille V, Guy Grand B, et al. (2001) Presence of increased stiffness of the common carotid artery and endothelial dysfunction in severely obese children: A prospective study. Lancet 358(9291): 1400-1404.

63. Aggoun Y, Farpour Lambert NJ, Marchand LM, Golay E, Maggio AB, et al. (2008) Impaired endothelial and smooth muscle functions and arterial stiffness appear before puberty in obese children and are associated with elevated ambulatory blood pressure. Eur Heart J 29(6): 792-799.

64. Dawson JD, Sonka M, Blecha MB, Lin W, Davis PH (2009) Risk factors associated with aortic and carotid intima-media thickness in adolescents and young adults: The Muscatine Offspring Study. J Am Coll Cardiol 53(24): 2273-2279.

65. Wong CY, O Moore Sullivan T, Leano R, Byrne N, Beller E, et al. (2004) Alterations of left ventricular myocardial characteristics associated with obesity. Circulation 110(19): 3081-3087.

66. Iacobellis G, Ribaudo MC, Zappaterreno A, Vecci E, Tiberti C, et al. (2003) Relationship of insulin sensitivity and left ventricular mass in uncomplicated obesity. Obes Res 11(4): 518-524.

67. Di Bonito P, Capaldo B, Forziato C, Sanguigno E, Di Fraia T, et al. (2008) Central adiposity and left ventricular mass in obese children. Nutr Metab Cardiovasc Dis 18(9): 613-617.

68. Levy D, Garrison RJ, Savage DD, Kannel WB, Castelli WP (1990) Prognostic implications of echocardiographically determined left ventricular mass in the Framingham Heart Study. N Engl J Med 322(22): 1561-1566.

69. Mehta SK (2014) Left ventricular mass in children and adolescents with elevated body mass index and normal waist circumference. Am J Cardiol 113(6): 1054-1057.

70. Maggio AB, Aggoun Y, Marchand LM, Martin XE, Herrmann F, et al. (2008) Associations among obesity, blood pressure, and left ventricular mass. J Pediatr 152(4): 489-493.

71. Sivanandam S, Sinaiko AR, Steffen L, Moran A, Steinberger J, et al. (2006) Relation of increase in adiposity to increase in left ventricular mass from childhood to young adulthood. Am J Cardiol 98(3): 411-415.

72. Daniels SR, Morrison JA, Sprecher DL, Khoury P, Kimball TR (1999) Association of body fat distribution and cardiovascular risk factors in children and adolescents. Circulation 99(4): 541-545.

73. Yusuf S, Hawken S, Ounpuu S, Dans T, Avezum A, et al. (2004) Interheart Study Investigators. Effect of potentially modifiable risk factors associated with myocardial infarction in 52 countries (the Interheart study): A case-control study. Lancet 364 (9438): 937-952.

74. Hirschler V, Acebo HL, Fernandez GB, Ferradas S, Oestreicher K (2012) Association between left atrial size and measures of adiposity among normal adolescent boys. Pediatr Cardiol 33(2): 245-251.

75. Hirschler V, Acebo HL, Fernandez GB, de Lujan Calcagno M, Gonzalez C, et al. (2006) Influence of obesity and insulin resistance on left atrial size in children. Pediatr Diabetes 7(1): 39-44.

76. Hoit BD (2014) Left atrial size and function: Role in prognosis. J Am Coll Cardiol 63(6): 493-505.

77. Sharpe JA, Naylor LH, Jones TW, Davis EA, O Driscoll G, et al. (2006) Impact of obesity on diastolic function in subjects $<$ or $=16$ years of age. Am J Cardiol 98(5): 691-693.

78. Peterson LR, Waggoner AD, Schechtman KB, Meyer T, Gropler, et al. (2004) Alterations in left ventricular structure and function in young, healthy obese women: Assessment by echocardiography and tissue doppler imaging. J Am Coll Cardiol 43(8): 1399-1404.

79. Schunkert H (2002) Obesity and target organ damage: The heart. Int J Obes Relat Metab Disord 26 (Suppl 4): S15-S20.

80. Lorell BH, Carabello BA (2000) Left ventricular hypertrophy: Pathogenesis, detection, and prognosis. Circulation 102(4): 470-479.

81. Umemura S, Nyui N, Tamura K, Hibi K, Yamaguchi S, et al. (1997) Plasma angiotensinogen concentrations in obese patients. Am J Hypertens 10(6): 629-633.

82. Sabri A, Hughie HH, Lucchesi PA (2003) Regulation of hypertrophic and apoptotic signaling pathways by reactive oxygen species in cardiac myocytes. Antiox Redox Signal 5(6): 731-740.

83. Sorescu D, Griendling KK (2002) Reactive oxygen species, mitochondria, and NAD (P) H oxidases in the development and progression of heart failure. Congest Heart Fail 8(3): 132-140.

84. Poli A, Tremoli E, Colombo A, Sirtori M, Pignoli P, et al. (1988) Ultrasonographic measurement of the common carotid artery wall thickness in hypercholesterolemic patients: A new model for the quantitation and follow-up of preclinical atherosclerosis in living human subjects. Atherosclerosis 70(3): 253-261.

85. Burke GL, Evans GW, Riley WA, Sharrett AR, Howard G, et al. (1995) Arterial wall thickness is associated with prevalent cardiovascular disease in middle-aged adults: The Atherosclerosis Risk in Communities (ARIC) study. Stroke 26(3): 386-391.

86. Chambless LE, Heiss G, Folsom AR, Rosamond W, Szklo M, et al. (1997) Association of coronary heart disease incidence with carotid arterial wall thickness and major risk factors: The Atherosclerosis Risk in Communities (ARIC) study, 1987-1993. Am J Epidemiol 146(6): 483494. 
87. Hodis HN, Mack WJ, LaBree L, Selzer RH, Liu CR, et al. (1998) The role of carotid arterial intima-media thickness in predicting clinical coronary events. Ann Intern Med 128(4): 262-269.

88. Urbina EM, Gidding SS, Bao W, Pickoff AS, Berdusis K, et al. (1995) Effect of body size, ponderosity, and blood pressure on left ventricular growth in children and young adults in the bogalusa heart study. Circulation 91(9): 2400-2406.

89. Gardin JM, Brunner D, Schreiner PJ, Xie X, Reid CL, et al. (2002) Demographics and correlates of five-year change in echocardiographic left ventricular mass in young black and white adult men and women: The Coronary Artery Risk Development in Young Adults (CARDIA) study. J Am Coll Cardiol 40(3): 529-535.

90. Must A, Jacques PF, Dallal GE, Bajema CJ, Dietz WH (1992) Long-term morbidity and mortality of overweight adolescents-a follow-up of the Harvard Growth Study of 1922 to 1935. N Engl J Med 327(19): 13501355.
91. Baker JL, Olsen LW, Sørensen TIA (2007) Childhood body-mass index and the risk of coronary heart disease in adulthood. N Engl J Med 357: 2329-2337.

92. Bibbins Domingo K, Coxson P, Pletcher MJ, Lightwood J, Goldman L (2007) Adolescent overweight and future adult coronary heart disease. N Engl J Med 357: 2371-2379.

93. Mangner N, Scheuermann K, Winzer E, Wagner I, Hoellriegel R, et al. (2014) Childhood obesity: Impact on cardiac geometry and function. JACC Cardiovasc Imaging 7(12): 1198-1205.

94. McGill HC, McMahan CA, Herderick EE, Malcom GT, Tracy RE, et al. (2000) Origin of atherosclerosis in childhood and adolescence. Am J Clin Nutr 72 (5 Suppl): 1307S-1315S. 